\title{
House Price Appreciation: The Impact Of No Income Verification Loans And Investor Activity
}

Lynne Kelly, Howard University, USA

\begin{abstract}
This paper examines house price appreciation in the US from 2004 through 2009, a period marked by a boom-and-bust cycle for house prices, to investigate the impact of the extensive use of no income verification loans and investor activity on house price movements. House price appreciation for each state and Washington, DC is modeled in cross-sectional time series regressions using macroeconomic variables and loan type intensities. The findings suggest that widespread use of no income verification loans and non-owner occupied loans directly impacts house price movements and significantly explains the astonishing gains and sudden losses that occurred during the sample period.
\end{abstract}

Keywords: house price appreciation; loan type; macroeconomic variables; cross-sectional time series regression

\section{INTRODUCTION}

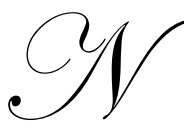

ominal house prices increased nationwide at an average rate of $4.3 \%$ per year from 2004 through 2009. House prices increased at an average rate of $9.5 \%$ per year from 2004 through 2006, but fell at an average rate of $1.0 \%$ per year from 2007 through 2009. While this boom-and-bust cycle was felt in many housing markets throughout the nation, there was tremendous variation in house price appreciation across states. In 2004, twenty states experienced double digit house price appreciation. California, Hawaii, and Nevada experienced the highest appreciation rates with $22.2 \%, 22.9 \%$, and $28.4 \%$, respectively. In 2007, house price appreciation slowed nationwide with ten states experiencing house price declines. By 2009, that number grew to forty-three states. Four of these states experienced double digit price declines that year, Arizona, California, Florida, and Nevada.

The disparate movement in house prices across states has led researchers to debate the existence of "housing bubbles" in several markets. While most researchers agree that housing became overvalued and a correction is taking place, there continues to be debate about the factors which led to the rapid gains and losses experienced in housing markets. One plausible explanation is that financial innovations led to decreases in lending standards and an expansion of mortgage credit. ${ }^{1}$ This created an environment in which borrowers with limited financial resources or impaired credit histories could become homeowners and investors could fund their activity more readily. The resultant increase in demand for housing caused dramatic house price appreciation. Subprime lending, in fact, has expanded rapidly in recent years and some borrowers were not required to document their incomes.

This paper examines house price appreciation across the US in order to gain insight into the key factors that explain house price movements. Using cross-sectional time series regressions, the importance of non-owner

\footnotetext{
${ }^{1}$ The Survey of Credit Underwriting Practices 2009 by the Office of the Comptroller of the Currency indicates that banks first eased and then tightened underwriting standards on residential mortgages over the sample period. In 2004, $7 \%$ of banks reported an easing of standards. In 2006, the percent of banks reporting easing peaked at $26 \%$. By 2009, the percent of banks reporting an easing of standards was $0 \%$. Reports of increased easing were driven primarily by stepped up competition. The methods of easing included: expanded use of stated income loans, increased interest only periods, higher loan-to-value and debt-to-income ratios, and protracted amortization.
} 
occupied loans and no income verification loans in explaining house price appreciation rates is examined. The findings reveal that these loan types significantly explain the tremendous house price gains and losses that occurred during the sample period. The paper proceeds as follows. In the second section, I provide a review of the literature on house price appreciation. In the third section, I provide a description of the methodology and data used in the analysis. In the fourth section, I present the empirical analysis. My conclusions are presented in the fifth section.

\section{LITERATURE REVIEW}

There have been numerous studies on house price dynamics, including several that examine the determinants of house price appreciation which is the focus of this study. ${ }^{2}$ Case and Shiller (1989) assess house price movement over time using the repeat sales methodology. They find considerable momentum in house price changes.

Case and Shiller (1990) model house price changes in four US metropolitan areas using variables that measure fundamental value relative to price. They find that the ratio of construction costs to price, changes in the adult population, and increases in income are positively related to house price changes over the subsequent year.

Peek and Wilcox (1991) estimate models of real house prices that incorporate financing, income, demographic, and cost factors for the period 1950-1989. The authors find that real after-tax mortgage rates, construction costs, and demographic factors account for much of the movement in real house prices.

Meese and Wallace (1993) test various specifications of housing market models and estimate them with data from the San Francisco area. The authors test the explanatory power of housing market supply and demand fundamentals such as construction costs, user costs, and income of potential homeowners along with a disequilibrium variable. They conclude that over long periods, fundamentals tend to explain house price movements.

Clapp and Giaccotto (1994) assess the value index for four towns in Connecticut and find that changes in unemployment, population, and income predict price changes.

Abraham and Hendershott (1996) develop a model to estimate fundamental house price levels which includes growth in real income, real construction costs, employment growth, and changes in the real after-tax interest rate. The authors assert that deviations of actual prices from the fundamental price level measure over or undervaluation in housing markets. The authors find that real house price appreciation is directly related to increases in real construction costs, employment and real income and negatively related to increases in real interest rates.

Malpezzi, Chun, and Green (1998) examine house prices using variables related to housing supply such as topographical and regulatory factors and variables related to housing demand such as income, population growth, number of persons per household, age of the head of the household, owner-occupancy, and proximity to parks. The authors find that house prices are related to population, income and demographic variables.

Jud and Winkler (2002) examine real house price appreciation in 130 metropolitan areas across the US. The authors find that real house price appreciation is influenced by population growth, real changes in income, construction costs, interest rates, and stock market index appreciation.

Capozza, Hendershott, and Mack (2004) summarize the literature on house price models. The authors assert that there is wide consensus that employment and population growth cause rents and prices to rise. In addition, house prices increase with income and decline with rising interest rates.

\footnotetext{
${ }^{2}$ For a comprehensive review of the literature on house price dynamics, see Cho (1996). For a review of US housing markets, see Green and Malpezzi (2003).
} 
Hung and Tu (2008) examine nominal house price appreciation in California from 1994 through 2004 using macroeconomic variables and the percentage of loans with adjustable rate mortgages (ARMs). The authors find that the use of ARMs significantly explains house price appreciation.

Mian and Sufi (2009) argue that increased securitization of mortgage loans has been associated with lax underwriting and an expansion of mortgage credit. The authors find that expansion of mortgage credit from 2002 through 2005 is linked to dramatic increases in house prices and subsequent increases in default and house price declines in zip codes that previously had high denial rates for mortgages.

\section{METHODOLOGY AND DATA}

The demand for housing in state (i) at time (t) is specified as:

$$
Q_{i, t}^{D}=f\left(P_{i, t}, Y_{i, t}, E_{i, t} I_{i, t}, \operatorname{Pop}_{i, t}, L_{i, t}\right)
$$

Where:

$$
\begin{aligned}
& P_{i, t}=\text { House price } \\
& Y_{i, t}=\text { Income } \\
& E_{i, t}=\text { Employment } \\
& I_{i, t}=\text { Interest rate } \\
& P_{o p_{i, t}}=\text { Population } \\
& L_{i, t}=\text { Loan type }
\end{aligned}
$$

Market supply is specified as:

$$
Q_{i, t}^{S}=f\left(P_{i, t}, I_{i, t}, C_{i, t}, \text { Permit }_{i, t}, S_{i, t}\right)
$$

Where:

$P_{i, t}=$ House price

$I_{i, t}=$ Interest rate

$C_{i, t}=$ Construction costs

Permit $_{i, t}=$ New housing permits

$S_{i, t}=$ State-specific factors

In equilibrium:

$$
Q_{i, t}^{D}=Q_{i, t}^{S}
$$

Combining equations (1) and (2) produces the following reduced form equation:

$$
P_{i, t}=f\left(Y_{i, t}, E_{i, t}, I_{i, t}, \text { Pop }_{i, t}, L_{i, t}, C_{i, t}, \text { Permit }_{i, t}, S_{i, t}\right)
$$


The percentage change in prices during any time period, $\% \Delta P_{i, t}$, is specified as:

$$
\% \Delta P_{i, t}=f\left(\% \Delta Y_{i, t}, \% \Delta E_{i, t}, \% \Delta I_{i, t}, \% \Delta P o p_{i, t}, \% \Delta L_{i, t}, \% \Delta C_{i, t}, \% \Delta P e r m i t_{i, t}, \% \Delta S_{i, t}\right)
$$

Equation (5) is estimated using a one-way fixed effects model with fixed state effects. The following demand-side variables are included: income growth, employment growth, 30-year mortgage rates, population growth, and loan type intensities. The loan type intensities include the percent of non-owner occupied loans and the percent of no income verification loans. The following supply-side variables are included: 30-year mortgage rates, construction cost growth, and new housing permit growth. New housing permit growth captures state-specific topographical constraints and regulations. Other state-specific factors are captured in the stated fixed effects. I also include lag house price appreciation to capture momentum in house price changes. All variable coefficients are assumed to be positive with the exception of mortgage rates. In the case of mortgage rates, I assume that shifts in demand associated with interest rate changes dominate shifts in supply. Therefore, mortgage rates are assumed to be negatively associated with house price appreciation. Also, I assume that investor activity, as captured by the percent of non-owner occupied loans, and the percent of no income verification loans positively impact house prices through the demand effect.

Exhibit 1 shows average annual house price appreciation across the US. House price appreciation peaked in 2005 and declined through 2009. Exhibit 2 shows average intensities for non-owner occupied loans and no income verification loans across the US. After 2007, the intensities of both loan types declined.

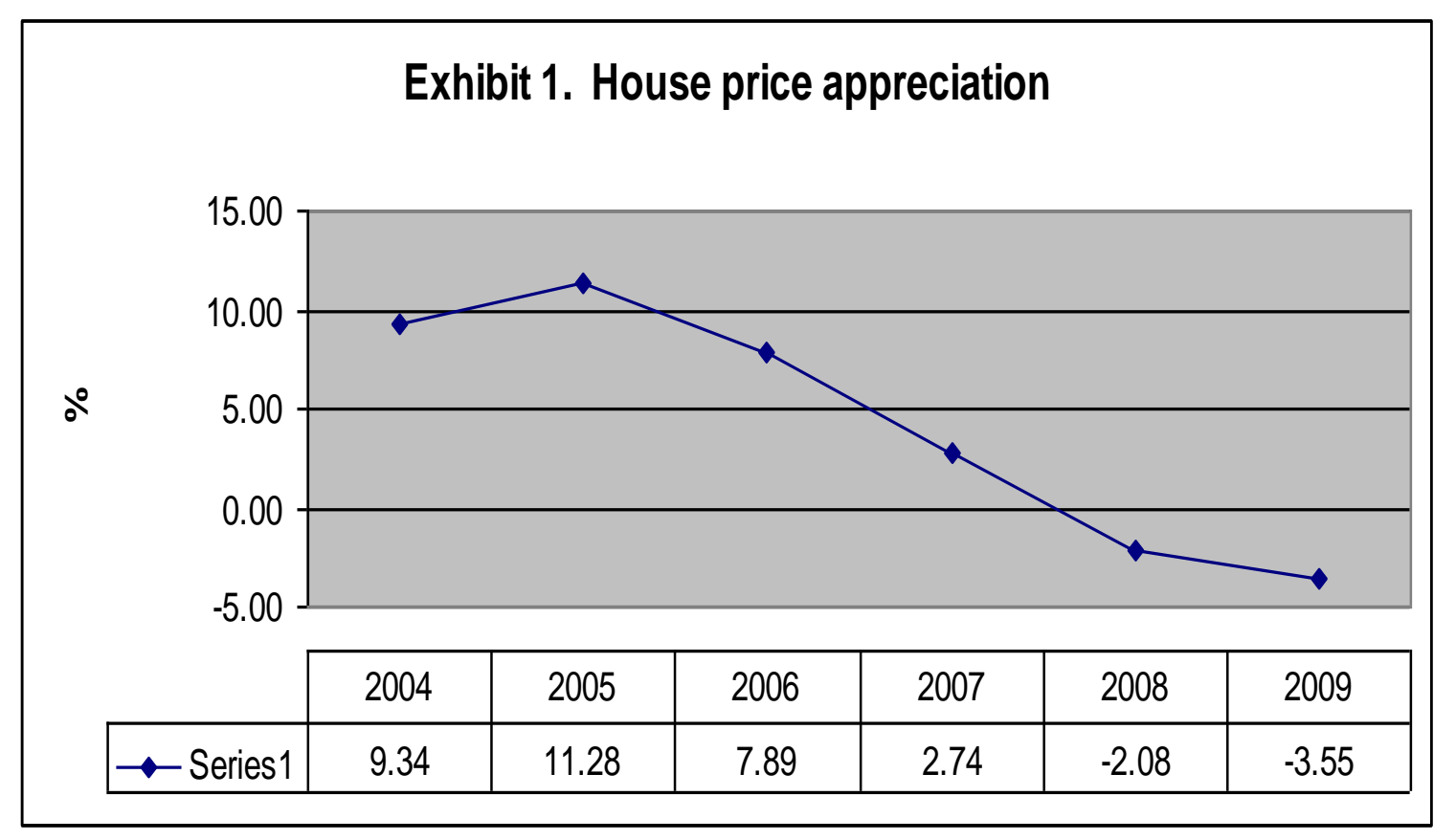




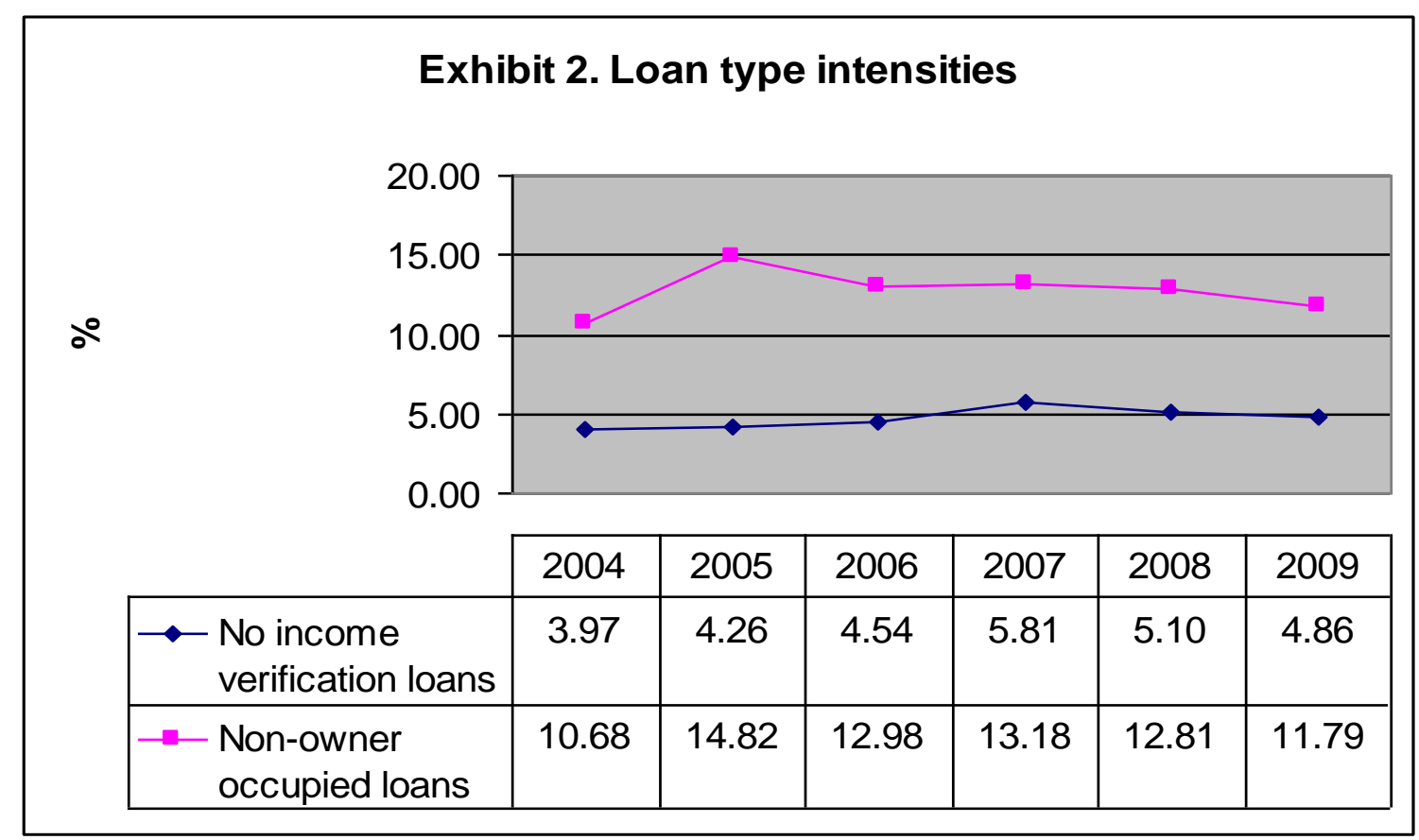

The data used to examine house price appreciation are detailed in Tables 1 and 2 . Table 1 provides variable definitions and data sources. Table 2 provides summary statistics.

Table 1: Variable Definitions And Data Sources

\begin{tabular}{|l|l|l|}
\hline \multicolumn{2}{|c|}{ Table 1: Variable Definitions And Data Sources } \\
\hline$\% \Delta \mathrm{P}$ & Definition & Source \\
\hline$\% \Delta \mathrm{Y}$ & Growth in per capita personal income & Federal Housing Finance Agency \\
\hline$\% \Delta \mathrm{E}$ & Employment growth rate & Bureau of Economic Analysis \\
\hline $\mathrm{I}$ & 30-year fixed mortgage rate & Bureau of Labor Statistics \\
\hline$\% \Delta \mathrm{Pop}$ & Resident population growth rate & Freddie Mac \\
\hline L_nonocc & Percent of non-owner occupied loans & Census Bureau \\
\hline L_niv & Percent of no income verification loans & Home Mortgage Disclosure Act \\
\hline$\% \Delta \mathrm{C}$ & Growth in price deflator index of new houses under construction & Home Mortgage Disclosure Act \\
\hline$\% \Delta$ Permit & Growth in new housing permits issued & Census Bureau \\
\hline
\end{tabular}

Table 2: Summary Statistics

\begin{tabular}{|l|c|c|c|c|}
\hline \multicolumn{1}{|c|}{ Variable } & Mean & Std. Dev. & Min. & Max. \\
\hline$\% \Delta \mathrm{P}$ & $4.27 \%$ & $6.19 \%$ & $-3.55 \%$ & $11.28 \%$ \\
\hline$\% \Delta \mathrm{Y}$ & $3.51 \%$ & $3.00 \%$ & $-2.11 \%$ & $6.28 \%$ \\
\hline$\% \Delta \mathrm{E}$ & $0.90 \%$ & $2.05 \%$ & $-2.93 \%$ & $2.16 \%$ \\
\hline I & $5.92 \%$ & $0.49 \%$ & $5.04 \%$ & $6.41 \%$ \\
\hline$\% \Delta$ Pop & $0.92 \%$ & $0.07 \%$ & $0.81 \%$ & $1.02 \%$ \\
\hline L_nonocc & $12.71 \%$ & $1.39 \%$ & $10.68 \%$ & $14.82 \%$ \\
\hline L_niv & $4.76 \%$ & $0.66 \%$ & $3.97 \%$ & $5.81 \%$ \\
\hline$\% \mathrm{C}$ & $2.56 \%$ & $5.45 \%$ & $-4.42 \%$ & $8.01 \%$ \\
\hline \% Permit & $-13.20 \%$ & $17.72 \%$ & $-34.35 \%$ & $9.98 \%$ \\
\hline
\end{tabular}




\section{EMPIRICAL ANALYSIS}

Table 3 shows the estimates of Equation (5) without the percent of non-owner occupied and no income verification loans included in the model. The F-test for no fixed effects indicates that a one-way fixed effects model is appropriate. The regression statistics show that $\mathrm{R}^{2}$ exceeds 0.88 . With the exception of growth in new housing permits issued, all variables exhibit the expected direction of influence. New housing permits directly impact house price appreciation. The result is significant at the $10 \%$ level of confidence. The only variable that does not significantly influence house price appreciation is population growth. This may be due to the fact that homeownership rates increased over the sample period, thereby impacting house prices more than population growth.

Table 3: House Price Appreciation Model

\begin{tabular}{|c|c|c|c|}
\hline Variable & Coefficient & t-stat & Pr $>\mathbf{t}$ \\
\hline$\% \Delta \mathrm{E}$ & 1.16 & 4.62 & $<.0001$ \\
\hline $\mathrm{I}$ & -8.39 & -9.16 & 0.0001 \\
\hline$\% \Delta$ Pop & 0.70 & 1.56 & 0.0002 \\
\hline$\% \Delta \mathrm{C}$ & 0.30 & 3.85 & 0.0762 \\
\hline$\% \Delta \mathrm{P} \_1$ & 0.03 & 1.78 & $<.0001$ \\
\hline R-sq & 0.63 & 14.38 & $<.0001$ \\
\hline
\end{tabular}

Table 4 shows the estimates of Equation (5) with the percent of non-owner occupied loans included in the model. The F-test for no fixed effects indicates that a one-way fixed effects model is appropriate. The regression statistics show that $\mathrm{R}^{2}$ exceeds 0.90 . The percent of non-owner occupied loans directly impacts house price appreciation, suggesting that increased investor activity increases house prices through a demand effect. The result is significant at the $1 \%$ level of confidence. All other results remain virtually the same.

Table 4: Impact Of Non-Owner Occupied Loans On House Price Appreciation

\begin{tabular}{|c|c|c|c|}
\hline Variable & Coefficient & t-stat & Pr $>\mathbf{t}$ \\
\hline$\% \Delta \mathrm{Y}$ & 0.48 & 3.72 & 0.0002 \\
\hline$\% \Delta \mathrm{E}$ & 1.19 & 5.04 & $<.0001$ \\
\hline $\mathrm{I}$ & -10.13 & -11.20 & 0.1542 \\
\hline$\%$ Pop & 0.60 & 1.43 & 0.0002 \\
\hline \% C Permit & 0.37 & 5.06 & 0.0906 \\
\hline$\% \Delta \mathrm{P} \_1$ & 0.03 & 1.70 & $<.0001$ \\
\hline L_nonocc & 0.67 & 16.17 & $<.0001$ \\
\hline R-sq & 0.66 & 5.99 & $<.0001$ \\
\hline
\end{tabular}

Table 5 shows the estimates of Equation (5) with the percent of no income verification loans included in the model. The F-test for no fixed effects indicates that a one-way fixed effects model is appropriate. The regression statistics show that $\mathrm{R}^{2}$ exceeds 0.89 . The percent of no income verification loans directly impacts house price appreciation, suggesting that these loans enable a greater number of borrowers to become homeowners and increase house prices through a demand effect. The result is significant at the $1 \%$ level of confidence. All other results remain virtually the same. 
Table 5: Impact Of No-Income Verification Loans On House Price Appreciation

\begin{tabular}{|c|c|c|c|}
\hline Variable & Coefficient & t-stat & Pr $>\mathbf{t}$ \\
\hline$\% \Delta \mathrm{Y}$ & 0.46 & 3.24 & 0.0014 \\
\hline$\% \Delta \mathrm{E}$ & 1.23 & 4.93 & $<.0001$ \\
\hline $\mathrm{I}$ & -8.04 & -8.79 & $<.0001$ \\
\hline$\% \Delta$ Pop & 0.58 & 1.28 & 0.2006 \\
\hline$\% \Delta \mathrm{C}$ & 0.31 & 4.00 & $<.0001$ \\
\hline$\% \Delta$ Permit & 0.03 & 1.72 & 0.0871 \\
\hline$\% \Delta \mathrm{P} \_1$ & 0.56 & 10.96 & $<.0001$ \\
\hline L_niv & 0.53 & 2.60 & 0.0099 \\
\hline R-sq & 0.8918 & F-test & 0.0004 \\
\hline
\end{tabular}

\section{CONCLUSIONS}

This paper examines house price appreciation in the US from 2004 through 2009 to investigate the impact of loan type intensities on house price movements. Previous studies show that house price appreciation is influenced by factors which impact housing demand such as income growth, employment growth, population growth, and mortgage interest rates as well as factors which influence housing supply such as construction cost growth and measures of state-specific topographical constraints and regulations. However, none of these studies examine the impact of non-owner occupied loans and no income verification loans on house price appreciation. Widespread use of non-owner occupied loans suggests increased investor activity in housing markets. Widespread use of no income verification loans likely results in a greater number of borrowers who are able to qualify for mortgage financing. Therefore, increased use of both loan types is expected to directly influence house price appreciation through a demand effect.

The results demonstrate that the percent of no income verification loans and non-owner occupied loans directly impacts house price appreciation and significantly explains the astonishing gains and sudden losses that occurred during the sample period.

\section{AUTHOR INFORMATION}

Lynne Kelly, Ph.D. is an Assistant Professor in the Department of Finance, International Business, and Insurance at Howard University in Washington, DC. She conducts research in the areas of real estate, international finance, and mutual fund performance. Her work appears in the Journal of Real Estate Finance and Economics and the Journal of Empirical Finance.

\section{REFERENCES}

1. Abraham, J. and P. Hendershott. 1996. Bubbles in Metropolitan Housing Markets. Journal of Housing Research. 7: 191-207.

2. Capozza, Dennis R., Hendershott, Patric H. and C. Mack. 2004. An Anatomy of Price Dynamics in Illiquid Markets: Analysis and Evidence from Local Housing Markets. Real Estate Economics. 32(1): 121.

3. Case, Karl E. and Robert J. Shiller. 1989. The Efficiency of the Market for Single Family Homes. American Economic Review 79: 125-137.

4. Case, Karl E. and Robert J. Shiller. 1990. Forecasting Prices and Excess Returns in the Housing Market. AREUEA Journal. 18(3): 252-273.

5. Cho, Man. 1996. House Price Dynamics: A Survey of Theoretical and Empirical Issues. Journal of Housing Research. 7(2): 145-172.

6. Clapp J.M. and C. Giacotto. 1994. The Influence of Economic Variables on Local House Price Dynamics. Journal of Urban Economics. 36(2): 161-183. 
7. Green, R.K. and S. Malpezzi. 2003. A Primer on US Housing Markets and Housing Policy. The Urban Institute, Washington, DC.

8. Hung, Szu-Yin Kathy and Charles Tu. 2008. An Examination of Housing Price Appreciation in California and the Impact of Alternative Mortgage Instruments. Journal of Housing Research. 17(1): 33-47.

9. Jud, G.D. and D.T. Winkler. 2002. The Dynamics of Metropolitan Housing Prices. Journal of Real Estate Research. 23(1/2): 29-45.

10. Malpezzi, S., Chun, G.H. and R.K. Green. 1998. New Place-to-Place Housing Price Indexes for US Metropolitan Areas, and Their Determinants. Real Estate Economics. 26(2): 235-274.

11. Meese, Richard A. and Nancy Wallace. 1993. Residential Housing Prices in San Francisco Bay Area: New Tests of the Explanatory Power of Economic Fundamentals. Working Paper. University of California at Berkeley.

12. Mian, Atif and Amir Sufi. 2009. The Consequences of Mortgage Credit Expansion: Evidence From The US Mortgage Default Crisis. Quarterly Journal of Economics. Nov: 1449-1496.

13. Office of the Comptroller of the Currency. The Survey of Credit Underwriting Practices 2009. Washington, DC.

14. Peek, Joe and James A. Wilcox. 1991. The Measurement and Determinants of Single-Family House Prices, AREUEA Journal. 19(3): 353-382. 